\title{
Analisis Pengaruh Marketing Mix Dalam Peningkatan Nasabah Tabungan Shar-e Pada PT. Bank Muamalat Indonesia Cabang Pekanbaru
}

\author{
Abdiana Ilosa $^{1}$ Zulhaida $^{2}$ \& Wenny Desty Febrian ${ }^{3}$ \\ 1,2,3 Fakultas Ekonomi dan Ilmu Sosial \\ Universitas Islam Negeri Sultan Syarif Kasim Riau \\ Jl. HR. Soebrantas Panam KM 15 No.155 Tampan Pekanbaru, 28293 \\ e-mail : ella.abdiana@yahoo.com; ida_puanri@yahoo.co.id; wenny.sani27@gmail.com
}

\begin{abstract}
Abstrak: Tujuan dari penelitian ini adalah untuk mengetahui bagaimana pengaruh marketing mix terhadap peningkatan nasabah tabungan shar-e pada PT. Bank Muamalat Indonesia Cabang Pekanbaru. Variabel yang diambil penelitian ini adalah produk, harga,promosi, distribusi, orang, proses dan fisik. Populasi dalam penelitian ini adalah nasabah yang menabung pada PT. Bank Muamalat Indonesia Cabang Pekanbaru yang berjumlah 43.770 orang. Sampel yang diambil sebagai responden sebanyak 100 orang (berdasarkan rumus Slovin. Dalam menganalisis data yang dikumpulkan digunakan metode regresi linier berganda, hasil analisis tersebut akan dianalisis dengan mengunakan bantuan program computer SPSS. Berdasarkan hasil program SPSS uji F menunjukkan bahwa nilai Sig. Hitung 0,013 < nilai Sig 0,05 maka dapat dinyatakan bahwa hipotesis Ho ditolak dan Ha diterima atau dapat dikatakan bahwa produk,harga,promosi,distribusi,orang,fisik dan proses secara bersama-sama berpengaruh terhadap Tabungan shar-e. Nilai koefisien Determinasi $\left(\mathrm{R}^{2}\right)$ sebesar 0,751 atau sebesar 75,10\%, hal ini menunjukkan bahwa ketujuh variabel bebas (produk, harga, promosi, distribusi, orang, fisik, proses) secara bersama-sama mampu menjelaskan terhadap variabel terikatnya sebesar $75,10 \%$, sedangkan sisanya $24,9 \%$ lagi (100-75,1) dapat diterangkan oleh variabel lain yang tidak diteliti dalam penelitian ini. Berdasarkan hasil program SPSS uji T nilai Sig. produk sebesar 0,004 < Sig. 0,05. Nilai Sig. harga sebesar $0,011<$ Sig. 0,05. Nilai Sig. promosi sebesar 0,012< Sig. 0,05 . Nilai Sig. distribusi sebesar 0,014< Sig. 0,05. Nilai Sig. orang sebesar 0,016< Sig. 0,05. Nilai Sig fisik sebesar $0,018<$ sig. 0,05. Nilai Sig proses sebesar 0,023 < Sig. 0,05. Dari ketujuh variabel tersebut hanya produk yang mempunyai nilai Sig lebih kecil dari keenam variabel lainnya hal ini menunjukan bahwa produk sangat berpengaruh terhadap Tabungan Shar-e.
\end{abstract}

Kata Kunci : Marketing Mix, Tabungan Shar-e 


\section{PENDAHULUAN}

Banyak yang mengatakan pasar Syariah adalah pasar yang emosional (emotional market) sedangkan pasar konvensional adalah pasar yang rasional (rational market). Maksudnya orang tertarik untuk berbisnis pada pasar Syariah karena alasan-alasan keagamaan (dalam hal ini agama Islam) yang lebih bersifat emosional, bukan karena ingin mendapatkan keuntungan financial yang bersifat rasional. Sebaliknya, pada pasar konvensional atau non-Syariah, orang ingin mendapatkan keuntungan yang sebesarbesarnya, tanpa terlalu peduli apakah bisnis yang digelutinya tersebut mungkin menyimpang atau malah bertentangan dengan ajaran agama (Islam).

Perkembangan bank-bank Syariah di Negara-negara Islam berpengaruh ke Indonesia, pada awal 1980-an diskusi mengenai bank syariah sebagai pilar ekonomi Islam mulai dilakukan. Para tokoh yang terlibat dalam kajian tersebut adalah Karnaen A. Perwataatmadja, M. Dewan Raharjo, A. M. Saefuddin, M. Amien Aziz, dan lain-lain. Beberapa uji coba pada sekala yang relative terbatas telah diwujudkan. Diantaranya adalah Baitul Tamwil-Salman, Bandung, yang sempat tumbuh mengesankan.

Akan tetapi, prakarsa lebih khusus untuk mendirikan bank Islam di Indonesia baru dilakukan pada tahun 1990. Majlis Ulama Indonesia (MUI) pada tanggal 18-20 Agustus 1990 menyelenggrakan Lokakarya Bunga Bank dan Perbankan di Cisarua, Bogor, Jawa Barat. Hasil lokakarya tersebut dibahas lebih mendalam pada Musyawarah Nasional IV MUI yang berlangsung di Hotel Sahid Jaya Jakarta, 22-25 agustus 1990. Dalam hal ini dibentuk tim kerja untuk mendirikan bank Islam di Indonesia.

Dengan perkembanga tersebut bank Syaraiah terutama dalam pembahasan ini bank Muamalat Indonesia harus lebih baik dalam produk dan jasa yang ditawarkan. Mulai dari produk, harga, promosi, distribusi, orang, proses dan fisik harus selalu diperhatikan yang mana ketujuh elemen ini sangat penting dalam peningkatan dan perkembangan bank Muamalat.

Bank merupakan satu lembaga keuangan yang memegang peranan penting dalam perekonomian suatu bangsa. Bank Syariah di Indonesia pertama kali diperkenalkan pada tahun 1992 sejalan dengan diberlakukanya Undang-undang No. 7 Tahun 1992 tentang perbankan. Namun, dalam kurun waktu 6 tahun perkembangan bank Syariah tidak sepesat bank-bank konvensional. Dengan diberlakukannya undang-undang perbankan No. 10 tahun 1998, perbankan Syariah diharapkan dapt berkembang lebih baik dan dapat menjadi salah satu kompenen penting dalam upaya pengembangan industri perbankan Indonesia.

Dengan adanya bank Syariah konsumen yang mayoritas beragama Islam tidak ragu dan bermaksud mengalokasikan dananya pada bank syariah dan sekaligus kegiatan operasionaol bank syariah lebih efektif dan maksimal.

Melihat perkembangan perbankan Syariah yang cukup pesat, bahakan pada tahun 1997-1998 terjadi kerisis yang melanda bukan saja Negara Indonesia yang pada saat itu hanya bank syariah yang bertahan yaitu Bank Muamalat Indonesia sama sekali tidak terkena damnpak kerisis tersebut. Bahkan sejak diberlakukannya Undang-Undang Perbankan No. 10 Tahun 1998, perbankan Syariah berkembang dengan pesat bank-bank umum mulai membuka unit-unit cabang Syariah, hal ini mengingat dalam Undang-Undang No. 10 tersebut perbankan Syariah diberi peluang lebih luas dalam menjalankan kegiatan 
usahanya, termasuk memberikan kesempatan pada bank konvensional untuk membuka kantor cabang yang khusus melakukan kegiatan usaha prinsip Syariah.

Oleh sebab itu, dengan adanya faktor-faktor Marketing Mix tersebut diharapkan bank dapat meningkatkan nasabahnya. Begitu juga sebaliknya, dengan adanya stimulus (rangsangan) yang diberikan oleh bank diharapkan nasabah tertarik untuk menabung, sehingga jumlah nasabah dapat terus berkembang.

Tabel 1 : Perkembangan Jenis Tabungan dan Jumlah Nasabah Pada Bank Muamalat Indonesia Pekanbaru Tahun 2015-2019

\begin{tabular}{|r|l|c|c|c|c|c|}
\hline \multirow{2}{*}{ No } & \multirow{2}{*}{ Jenis Tabungan } & \multicolumn{5}{|c|}{ Jumlah Nasabah } \\
\cline { 3 - 7 } & & $\mathbf{2 0 1 5}$ & $\mathbf{2 0 1 6}$ & $\mathbf{2 0 1 7}$ & $\mathbf{2 0 1 8}$ & $\mathbf{2 0 1 9}$ \\
\hline 1 & Tabungan & & & & & \\
\hline & a. Tabungan Umat & 1801 & 1992 & 2301 & 2517 & 1497 \\
\hline & b. Tabungan Umat Junior & 4029 & 4598 & 5907 & 6835 & 8437 \\
\hline & c. Tabungan Arafah & 986 & 1041 & 1693 & 1836 & 2189 \\
\hline & d. Tabungan Shar-e & 10210 & 15986 & 18974 & 22184 & 30410 \\
\hline 2 & Giro & 143 & 184 & 209 & 289 & 349 \\
\hline 3 & Deposito & & & & & \\
\hline & a. Rupiah & 347 & 542 & 679 & 814 & 856 \\
\hline & b. Valuta Asing & 18 & 23 & 31 & 37 & 32 \\
\hline
\end{tabular}

Sumber : PT. Bank Muamalat Indonesia Cabang Pekanbaru

Dari tabel di atas dapat kita analisa perkembangan jumlah nasabah 2015-2016 sebesar 6832 orang nasabah atau $28,96 \%$, pada tahun 2016-2017 jumlah nasabah

\section{TINJAUAN PUSTAKA}

\section{Pengertian Pemasaran}

Kegiatan pemasaran selalu ada dalam setiap usaha, baik yang berorientasi profit maupun usaha-usaha sosial. Pentingnya pemasaran dilakukan dalam rangka memenuhi kebutuhan dan keinginan masyarakat akan suatu produk dan jasa.

Para ahli banyak mendefinisikan pengertian dari pemasaran. Diantarannya, pemasaran merupakan hasil prestasi kegiatan usaha yang berkaitan dengan mengalirnya barang dan jasa dari produsen sampai konsumen. Selain itu pemasaran merupakan kegiatan manusia yang diarahkan untuk memenuhi dan memuaskan kebutuhan serta keinginan bertambah sebesar 5422 orang nasabah atau $22,25 \%$ terjadi penurunan persentase, pada tahun 2017-2018 jumlah nasabah bertambah 4274 atau $15,86 \%$.

melalui proses pertukaran. (Assauri, 2004:3)

Pemasaran adalah proses sosial dan manajerial dimana individu dan kelompok mendapatkan kebutuhan, keinginan mereka dengan menciptakan, menawarkan dan menukarkan produk yang bernilai satu sama lain. (Susanto, 2000:19)

Pemasaran adalah proses merancanakan dan melaksanakan konsep, memberi harga, melakukan promosi dan mendistribusikan ide, barang dan jasa untuk menciptakan pertukaran yang memenuhi tujuan individu dan organisasi. (McDaniel, 2001: 4). Pemasaran adalah sesuatu yang dapat memenuhi kebutuhan sambil mendapatkan keuntungan. (Kotler, 2004:4). Pemasaran bank adalah usaha untuk memenuhi kebutuhan dan keinginan 
para nasabahnya terhadap produk dan jasa. (Kasmir, 2005: 61). Jadi, dapat disimpulkan bahwa Pemasaran adalah proses sosial yang didalamnya individu dan kelompok mendapatkan apa yang mereka butuhkan dan inginkan untuk mendapatkan keuntungan dengan menciptakan, menawarkan dan secara bebas mempertukarkan produk yang bernilai dengan pihak lain.

Dalam Syariah marketing memiliki pengertian yang lebih bukan sekedar mendapatkan apa yang mereka butuhkan dan inginkan untuk mendapatkan keuntungan dengan menciptakan, menawarkan dan secara bebas mempertukarkan produk yang bernilai dengan pihak lain. Namun harus sesuai dengan akad dan prinsif-prinsif muamalah (bisnis) dalam Islam.

Pemasaran berdasarkan Syariah adalah sebuah disiplin bisnis strategis yang mengarahkan proses penciptaan, penawaran, dan perubahan value dari suatu inisiator kapada stakeholders-nya, yang dalam keseluruhan prosesnya sesuai dengan akad dan prinsif-prinsif muamalah (bisnis) dalam Islam. (Kartajaya dan Sula, 2006: xxvi-xxvii)

Syariah Marketing adalah sebuah disiplin bisnis strategis yang mengrahkan proses penciptaan, penawaran, dan perubahan value dari suatu inisiator kepada stakeholder-nya, yang dalam keseluruhan prosesnya sesuai dengan akad dan prinsip-prinsip muamalah. (bisnis) dalam Islam. Pada intinya, dalam menentukan marketing mix proses integrasi terhadap offer dan access, haruslah didasari oleh prinsip-prinsip keadilan dan kejujuran. (Kartajaya dan Sula, 2006:26-27).

Definisi di atas didasarkan pada salah satu ketentuan dalam bisnis Islami yang tertuang dalam kaidah fiqih yang
mengatakan,"Al-muslimuna

'ala syurutihihim illa syarthan harrama halalan wa ahalla harama" (kaum Muslimin terikat dengan kesepakatan-kesepakatan bisnis yang mereka buat, kecuali kesepakakatan yang mengharamkan yang halal atau yang menghalalkan yang haram). Selain itu, kaedah fiqih lain mengatakan "Al-ashlu filmu'amalah al-ibahah illa ayyadulla dalilun "ala tahrimiha" (pada dasarnya semua bentuk muamalah [bisnis] boleh dilakukan kecuali ada dalil yang mengharamkannya). (Kartajaya dan Sula, 2006:27).

\section{Pengertian Marketing Mix}

Marketing mix merupakan unsurunsur pemasaran yang saling terkait, dibaurkan diorganisir dan digunakan dengan tepat, sehinnga perusahaan dapat tujuan pemasaran dengan efektif, sekaligus memuaskan kebutuhan dan keinginan konsumen. (Buchari Alma dan Ratih Hurriyati, 2008:154)

Marketing mix terdiri dari himpunan variable yang dapat dikendalikan digunakan oleh perusahaan untuk mempengaruhi tanggapan konsumen dalam pasar sasarannya. (Assauri, 2004:198)

Marketing mix merupakan suatu perangkat yang akan menentukan tingkat keberhasilan pemasaran oleh perusahaan dan semua ini ditujukan untuk memberikan kepuasan kepada segmen pasar atau konsumen yang dipilih. (Hamzah, dkk, 2019).

Bauran pemasaran (Marketing Mix) merupakan alat bagi pemasar yang terdiri atas berbagai unsur suatu program pemasaran yang perlu dipertimbangkan agar implementasi strategi pemasaran dan positioning yang ditetapkan dapat berjalan sukses. (Rambat dan Hamdani, 2006:70)

Bauran pada produk barang mencangkup 4P: product, price, place dan promotion. Sedangkan untuk jasa keempat 
hal tersebut masih dirasa kurang mencukupi. Para pakar pemasaran menambahkan tiga unsur lagi: peole, process dan physic. Ketiga hal ini terkait dengan sifat jasa dimana tahapan operasi hingga konsumsi merupakan suatu rangkaian yang tidak dapat dipisahkan serta mengikutsertakan konsumen dan pemberi jasa secara lansung, demgan kata lain terjadi intraksi langsung antara keduanya (meski tidak untuk semua jasa). (Rambat dan Hamdani, 2006:70)

\section{Pengertian Bank}

Bank adalah lembaga keuangan yang kegiatan usahannya adalah menghimpun dana dari masyarakat dan menyalurkan kembali dana tersebut kemasyarakat serta memberikan jasa-jasa bank lainnya. Menurut Undang-Undang Nomor 10 Tahun 1998 bank adalah badan usaha yang menghimpun dana dari masyarakat dalam bentuk simpanan dan menyalurkannya kemasyarakat dalam bentuk kredit dan atau bentuk-bentuk lainnya dalam rangka meningkatkan taraf hidup rakyat banyak. (Kasmir, 2005: 8-9)

Bank adalah suatu lembaga yang melaksanakan tiga fungsi yaitu, menerima simpanan uang, meminjamkan uang dan memberikan jasa pengiriman barang. (Adi warman Karim, 2004:18)

Bank Syariah adalah dengan pola bagi hasil yang merupakan landasan utama dalam segala operasinya, baik dalam produk pendanaan, pembiayaan, maupun dalam peruduk lainnya. (Ascarya, 2008:2)

\section{METODE}

\section{Lokasi Penelitian}

Penelitian ini pada Bank Muamalat Indonesia Cabang Pekanbaru yang berlokasi di Jalan Jenderal Sudirman Pekanbaru.

\section{Jenis Dan Sumber Data}

Data yang diperlukan dalam penelitian ini dapat dikelompokan kedalam dua kelompok data:

a. Data Primer. Yaitu data yang didapat dari sumber pertama baik dari individu maupun wawancara secara langsung dengan pihak Bank dan nasabah serta penyebaran angket kepada responden.

b. Data Sekunder. Yaitu data yang telah diolah dan disiapkan oleh pihak Bank berupa data jumlah dan jenis pekerjaan nasabah, sejarah singkat perusahaan, struktur perusahaan, serta aktivitas perusahaan.

\section{Teknik Pengumpulan Data}

Untuk memecahkan masalah yang dihadapi dalam masalah ini dilakukan teknik pengumpulan data dalam bentuk yaitu:

1. Wawancara (interview). Yaitu cara pengumpulan data dengan mengadakan wawancara kepada pihak pimpinan maupun karyawan perusahaan tentang masalah yang ada hubunganya dalam masalah ini.

2. Kuesioner. Yaitu suatu teknik pengumpulan data yang dilakukan dengan cara menggunakan daftar pertanyaan yang diajukan kepada nasabah Bank Muamalat Indonesia Cabang Pekanbaru yang disebut dengan responden yang berhubungan dengan penelitian.

\section{Populasi Dan Sampel}

Populasi adalah wilayah generalisasi yang terdiri atas objek atau subjek yang mempunyai kualitas dan karakteristik tertentu yang ditetapkan oleh peneliti untuk dipelajari kemudian ditarik kesimpulannya. Dalam pengambilan data yang menjadi populasi untuk penelitian ini adalah nasabah jasa pada bank Muamalat Indonesia Cabang Pekanbaru dalam priode tertentu. 
Sampel adalah bagian dari jumlah dan karakteristik yang dimiliki populasi. Untuk menentukan sempel, maka penulis menerapkan teori slovin.

Keterangan:

$$
\mathrm{n}=\frac{\mathrm{N}}{1+\mathrm{Ne}^{2}}
$$

$\mathrm{N}=$ Jumlah Sampel

$\mathrm{N}$ = Besar Populasi, yang diambil pada tahun 2007 sebesar 34.512

e = Nilai Kritis (batas ketelitian) yang diinginkan kelonggaran (persentase kesalahan penarikan karena kesalahan penarikan sampel) sebesar $10 \%$.

$$
n=\frac{34.512}{1+34.512(0,1)^{2}}
$$

$$
\begin{aligned}
n & =\frac{34.512}{346,12} \\
& =99,71
\end{aligned}
$$

Jadi, jumlah sampel yang diperlukan sebesar 100 nasabah Bank Muamalat Indonesia Cabang Pekanbaru.

\section{HASIL PENELITIAN \\ Uji Normalitas Data}

Uji normalitas data yang digunakan dalam penelitian ini adalah kolmogorofsmirnof, kriteria ujinya adalah jika setiap variabel menghasilkan K-S-Z dengan $P$ value / Sig. (2-Tailed) > 0,05 hal ini menunjukan bahwa data normal dan sebaliknya.

Tabel 2 : Analis Uji Normalitas Setiap Variabel Penelitian

\begin{tabular}{|l|c|c|}
\hline \multicolumn{1}{|c|}{ Variabel } & Sig. (2-Tailed) & Sig. 5 \% \\
\hline Tabungan Shar-e & 0.48 & 0,05 \\
\hline Produk/produck(X1) & 0,054 & 0,05 \\
\hline Harga/price (X2) & 0,406 & 0,05 \\
\hline Promosi/promotion (X3) & 0,071 & 0,05 \\
\hline Distribusi/place (X4) & 0,060 & 0,05 \\
\hline Orang/people (X5) & 0,084 & 0,05 \\
\hline Fisik/physical (X6) & 0,058 & 0,05 \\
\hline Proses/proses (X7) & 0,063 & 0,05 \\
\hline
\end{tabular}

Sumber : Output SPSS

Dari tabel 2 di atas menunjukan bahwa masing-masing variabel sig. (2tailed) > Sig. 0,05. Dimana Sig. (2-tailed) produk 0,054 $>0,05$. Sig. (2-tailed) harga $0,406>0,05$. Sig. (2-tailed) promosi $0,071>$ 0,05. Sig. (2-tailed) distribusi 0,060 >0,05. Sig. (2-tailed) orang 0,084 > 0,05. Sig. (2- tailed) fisik 0,058 $>0,05$. Sig.(2-tailed) proses $0,63>0.05$. hal ini menunjukan bahwa data normal.

Analisis Regresi Linear Berganda

Berdasarkan hasil perhitungan dengan menggunakan SPPS 12 diperoleh data-data sebagai berikut.

Tabel 3 : Koefisien Regresi dan Standar Error

\begin{tabular}{|l|c|c|c|c|}
\hline \multicolumn{1}{|c|}{ Variabel } & $\begin{array}{c}\text { Koefisien } \\
\text { Regresi }\end{array}$ & $\begin{array}{c}\text { Standar } \\
\text { Error }\end{array}$ & T hitung & Sig \\
\hline produk (X1) & .448 & .042 & 6.878 & .004 \\
\hline harga (X2) & .404 & .056 & 6.450 & .011 \\
\hline promosi (X3) & .389 & .058 & 5.575 & .012 \\
\hline Distibusi (X4) & .372 & .059 & 5.150 & .014 \\
\hline Orang(X5) & .311 & .061 & 5.046 & .016 \\
\hline
\end{tabular}




\begin{tabular}{|l|c|c|c|c|}
\hline Fisik (X6) & .304 & .064 & 5.032 & .018 \\
\hline Proses (X7) & .300 & .058 & 5.026 & .023 \\
\hline Constant (a) & 4.370 & 1.474 & 4.766 & .024 \\
\hline R square : 0,751 & \multicolumn{5}{l}{} \\
R : 0,867 & & & \\
F Ratio : 6,401 & & & \\
Sig : 0,013 & & & \\
\end{tabular}

Sumber : Output SPSS

Berdasarkan tabel 3 di atas maka dapat diketahui bahwa persamaan regresi linear berganda dalam analisis sebagai berikut:

$\mathrm{Y}=4,370+0,448 \mathrm{X} 1+0,404 \mathrm{X} 2+0,389 \mathrm{X} 3$ $+0,372 X 4+0,311 X 5+0,304 X 6+0,300$ $\mathrm{X} 7$

Keterangan:

1. Y (Tabungan Shar-e) mempunyai nilai konstanta sebesar 4,370 Ini berarti bahwa jika variabel X1, X2, X3, X4, X5, X6, X7 dianggap nol, maka nilai perilaku konsumen sebesar 4,370.

2. Koefisien X1 (produk) sebesar 0,448 menyatakan bahwa setiap penambahan satu-satuan motivasi maka akan meningkatkan Tabungan Shar-e sebesar 0,448 satuan.

3. Koefisien X2 (harga) sebesar 0,404 menyatakan bahwa setiap penambahan satu-satuan persepsi akan meningkatkan Tabungan Shar-e sebesar 0,404 satuan.

4. Koefisien X3 (promosi) sebesar 0,389 menyatakan bahwa setiap penambahan satu-satuan pembelajaran maka akan meningkatkan variabel Tabungan Share sebesar 0,389 satuan.

5. koefisien $\mathrm{X} 4$ (distribusi) sebesar 0,372 menyatakan bahwa setiap penambahan satu-satuan keyakinan akan meningkatkan variabel Tabungan Share sebesar 0,372 satuan.
6. koefisien X5 (orang) sebesar 0,311 menyatakan bahwa setiap penambahan satu-satuan sikap akan meningkatkan variabel Tabungan Shar-e sebesar 0,311 satuan.

7. koefisien X6 (fisik) sebesar 0,304 menyatakan bahwa setiap penambahan satu-satuan sikap akan meningkatkan variabel Tabungan Shar-e sebesar 0,311 satuan.

8. koefisien X7 (proses) sebesar 0,300 menyatakan bahwa setiap penambahan satu-satuan sikap akan meningkatkan variabel Tabungan Shar-e sebesar 0,311 satuan.

Dari persamaan regresi diatas diketahui bahwa variabel X1 (produk), X2 (harga), dan X3 (promosi), X4 (distribusi), X5 (orang), X6 (fisik), dan X7 (proses) berniliai positif. Hal ini menunjukkan bahwa semakin tinggi nilai dari ketujuh variabel tersebut maka konsumen akan semakin bertambah untuk menabung pada PT. Bank Muamalat Indonesia Pekanbaru.

Koefisien Determinasi ( $\left.\mathbf{R}^{2}\right)$ / R Square

Koefisien determinasi $\left(\mathrm{R}^{2}\right)$ pada intinya mengukur seberapa jauh kemampuan menerangkan variasi variabel dependen $(Y)$. Nilai koefisien determinasi antara nol dan satu. Nilai $\mathrm{R}^{2}$ kecil berarti kemampuan variabel-variabel independen dalam menjelaskan variabel dependen amat terbatas. Berdasarkan tabel V. 29 diatas dapat diketahui bahwa nilai koefisien determinasi $\left(\mathrm{R}^{2}\right)$ sebesar 0,751 
atau sebesar $75,10 \%$, hal ini menunjukkan bahwa ketujuh variabel bebas (produk, harga, promosi, distribusi, orang, fisik, proses) secara bersama-sama mampu menjelaskan terhadap variabel terikatnya sebesar $75,10 \%$ sedangkan sisanya $24,9 \%$ lagi $(100$ - 75,1) dapat diterangkan oleh variabel lain yang tidak diteliti pada penelitian ini.

Uji F (F test)

Uji f pada dasarnya menunjukkan apakah semua variabel independen atau bebas mempunyai pengaruh secara bersama-sama (simultan) terhadap variabel dependen atau terikat.

Untuk membuktikan hal tersebut, maka dilakukan uji F. Sebelum melakukan pengujian, dapat dirumuskan hipotesis sebagai berikut:

Ho : Faktor produk, harga, promosi, distribusi, orang, fisik, proses tidak berpengaruh secara signifikan terhadap Tabungan Shar-e

Ha : Faktor produk, harga, promosi, distribusi, orang, fisik, proses berpengaruh secara signifikan terhadap Tabungan Shar-e.

Pengambilan keputusan dalam uji signifikansi uji $\mathrm{F}$ ini dilakukan dengan kriteria : (Ghozali, 2005: 58).

a) Jika (P value / Sig) $<0,05$ maka Ho ditolak atau Ha diterima

b) Jika ( $\mathrm{P}$ value / Sig) > 0,05 maka Ho diterima atau Ha ditolak.

Tabel 4 : Analisis Variabel Independen Simultan Terhadap Variabel Dependen (Uji F)

\begin{tabular}{|c|c|c|}
\hline $\mathrm{F}$ & Sig & Sig. 5\% \\
\hline 6,401 & 0,013 & 0,05 \\
\hline
\end{tabular}

Sumber : Output SPSS

Dari tabel 4 di atas dapat diketahui nilai signifikansi yang dihasilkan oleh variable produk, harga, promosi, distribusi, orang, fisik, proses sebesar $0,013<0,05$ artinya semua variabel mempunyai pengaruh yang signifikan terhadap Tabungan Shar-e.

Dengan demikian hipotesis yang menyatakan variabel-variabel bebas mempunyai pengaruh terhadap Tabungan Shar-e dapat diterima.

\section{Uji T (Korelasi Parsial)}

Uji $t$ digunakan mengetahui pengaruh masing-masing variabel bebas terhadap variabel terikat secara individual atau parsial serta untuk mengetahui variabel bebas yang mempunyai pengaruh dominan terhadap variabel terikat dengan mengukur derajat hubungan antara variabel bebas dengan variabel terikat dengan menganggap variabel bebas lainnya bersifat konstan.

Untuk menganalisa pengaruh masing-masing variabel bebas dapat dirumuskan hipotesis sebagai berikut:

1. Variabel produk/produck(X1)

Ho : Faktor produk tidak berpengaruh secara signifikan terhadap Tabungan Shar-e.

Ha : Faktor produk berpengaruh secara signifikan terhadap Tabungan Shar-e.

2. Variabel harga/price (X2)

Ho : Faktor harga tidak berpengaruh secara signifikan terhadap Tabungan Shar-e.

Ha : Faktor harga berpengaruh secara signifikan terhadap Tabungan Shar-e.

3. Variabel Promosi/promotion (X3) 
Ho : Faktor Promosi tidak berpengaruh secara signifikan terhadap Tabungan Shar-e.

Ha : Faktor promosi berpengaruh secara signifikan terhadap Tabungan Shar-e.

4. Variabel Distibusi/place (X4)

Ho : Faktor distribusi tidak berpengaruh secara signifikan terhadap Tabungan Shar-e

Ha : Faktor distribusi berpengaruh secara signifikan terhadap Tabungan Shar-e

5. Variabel orang/people (X5)

Ho : Faktor orang tidak berpengaruh secara signifikan terhadap Tabungan Shar-e

Ha : Faktor orang berpengaruh secara signifikan terhadap Tabungan Shar-e

6. Variabel fisik/physical (X5)

Ho : Faktor fisik tidak berpengaruh secara signifikan terhadap Tabungan Shar-e
Ha : Faktor fisik berpengaruh secara signifikan terhadap Tabungan Shar-e

7. Variabel proses/proses (X5)

Ho : Faktor proses tidak berpengaruh secara signifikan terhadapTabungan Shar-e

Ha : Faktor proses berpengaruh secara signifikan terhadap Tabungan Shar-e

Pengambilan keputusan dalam uji T atau korelasi parsial ini dilakukan dengan kriteria: (Ghozali, 2005: 58).

a) Jika ( $\mathrm{P}$ value / Sig) < 0,05 maka Ho ditolak atau Ha diterima

b) Jika ( $\mathrm{P}$ value / Sig) > 0,05 maka Ho diterima atau Ha ditolak

Berdasarkan perhitungan dengan menggunakan program komputer SPSS 12 dapat diketahui hasil analisis koefisien regresi seperti pada tabel 39:

Tabel 5 : Analisis Variabel Bebas Secara Parsial Terhadap Variabel Terikat (uji T)

\begin{tabular}{|c|c|c|}
\hline Variabel & Sig & Sig. 5\% \\
\hline Produk/produck (X1) & .004 & 0,05 \\
\hline Harga/price (X2) & .011 & 0,05 \\
\hline Promosi/promotion (X3) & .012 & 0,05 \\
\hline Distribusi/place (X4) & .014 & 0,05 \\
\hline Orang/people (X5) & .016 & 0,05 \\
\hline Fisik/physical (X6) & .018 & 0,05 \\
\hline Proses/proses (X7) & .020 & 0,05 \\
\hline
\end{tabular}

Sumber : Output SPSS

Dari tabel 5 di atas diperoleh hasil dari pengujian parsial variabel bebas adalah sebagai berikut:

1. Variabel produk/produck (X1) menunjukkan nilai Sig sebesar $0,004<$ 0,05 . Hal ini menunjukkan bahwa Ha diterima dan variabel produk (X1) mempunyai pengaruh positif terhadap Tabungan Shar-e.

2. Variabel harga/price

menunjukkan nilai sig sebesar 0,011 < 0,05 . Hal ini menunjukkan bahwa $\mathrm{Ha}$ diterima dan variabel Harga (X2) mempunyai pengaruh positif terhadap Tabungan Shar-e. 
3. Variabel Promosi/promotion (X3) menunjukkan nilai Sig sebesar 0,012 < 0,05 . Hal ini menunjukkan bahwa $\mathrm{Ha}$ diterima dan variabel promosi (X3) mempunyai pengaruh positif terhadap Tabungan Shar-e.

4. Variabel distribusi/place (X4) menunjukkan nilai Sig sebesar 0,014 < 0,05 . Hal ini menunjukkan bahwa Ha diterima dan variabel distribusi (X4) mempunyai pengaruh positif terhadap Tabungan Shar-e.

5. Variabel orang/people menunjukkan nilai Sig sebesar 0,016 < 0,05 . Hal ini menunjukkan bahwa Ha diterima dan variabel orang (X5) mempunyai pengaruh positif terhadap Tabungan Shar-e.

6. Variabel fisik/physical menunjukkan nilai Sig sebesar 0,018 < 0,05 . Hal ini menunjukkan bahwa $\mathrm{Ha}$ diterima dan variabel fisik (X6) mempunyai pengaruh positif terhadap Tabungan Shar-e.

7. Variabel proses/proses menunjukkan nilai Sig sebesar 0,023 < 0,05 . Hal ini menunjukkan bahwa Ha diterima dan variabel proses (X7) mempunyai pengaruh positif terhadap Tabungan Shar-e.

Dari hasil pengujian masing-masing variabel bebas di atas dapat disimpulkan bahwa ketujuh variabel tersebut mempunyai pengaruh terhadap Tabungan Shar-e., karena nilai Signifikansi dari ketujuh variabel (produk, harga, promosi, distribusi, orang, fisik, proses) lebih kecil dari taraf signifikansi 0,05, dan yang paling berpengaruh dominan terhadap Tabungan Shar-e. pada PT. Bank Muamalat Indonesia Pekanbaru adalah variable produk, nasabah memiliki dorongan yang kuat untuk menabung pada PT. Bank Muamalat Indonesia Cabang Pekanbaru hal ini dikarenakan produk dari PT. Bank
Muamalat Indonesia berbasis syariat Islam dalam operasional menabung, adanya sistem bagi hasil yang berbeda dengan sistem bunga pada bank konvensional dan nasabah merasakan bahwa menabung pada PT. Bank Muamalat Indonesia Cabang Pekanbaru merupakan suatu kebutuhan.

\section{PEMBAHASAN}

Pada penjelasan sebelumnya telah dilakukan pengolahan data yang diperoleh dari responden yang kemudian diolah dengan menggunakan program Komputer SPSS 12, setelah itu dilakukan pembuktian hipotesis. Dari hasil tersebut dapat dijelaskan variabel bebas (produk, harga, pomosi, distribusi, orang, fisik, proses) mempunyai pengaruh yang signifikan terhadap variabel terikat (Tabungan Share).

Variabel pertama yang mempengaruhi Tabungan Shar-e. adalah produk menurut responden menabung pada PT. Bank Muamalat Indonesia Cabang Pekanbaru merupakan salah satu metode untuk menjalankan syariat Islam, sistem bagi hasil yang diterapkan sangat berbeda dengan sistem bunga yang diterapkan Bank Konvensional pada umumnya selain itu responden juga menyatakan bahwa menabung pada PT. Bank Muamalat Indonesia merupakan suatu kebutuhan untuk berinvestasi di masa depan.

Variabel kedua yang mempengaruhi Tabungan Shar-e. adalah harga karena responden memiliki penilaian atau penafsiran yang positif terhadap PT. Bank Muamalat Indonesia Cabang Pekanbaru karena merupakan lembaga keuangan yang menerapkan konsep syariat Islam, selain itu PT. Bank Muamalat Indonesia Cabang Pekanbaru dapat memberikan pelayanan yang sesuai dengan harapan nasabah serta produk tabungan yang ditawarkan dapat 
memenuhi kebutuhan atau keinginan nasabah.

Variabel ketiga yang mempengaruhi Tabungan Shar-e. adalah promosi karena dengan adanya promosi maka produk kita akan banyak diketahui oleh para konsumen, komunikasi yang memberikan penjelasan yang meyakinkan calon konsumen tentang barang dan jasa yang akan dijual . Tujun promosi sendiri adalah memperoleh perhatian, mendidik, mengingatkan dan menyakinkan calon konsumen.

Variabel keempat yang mempengaruhi Tabungan Shar-e adalah Distribusi karena semakin mudah konsumen mendapatkan produk yang dijual oleh perusahaan jasa angkutan ekspedisi maka akan semakin banyak lah pendapatan yang meraka peroleh dengan demikian persaingan antar perusahaan yang sejenis terjadi dalam mendistribusikan produknya.

Variabel kelima adalah orang juga dianggap dapat mempengaruhi Tabungan Shar-e karena menurut responden PT. Bank Muamalat Indonesia Cabang Pekanbaru menempatkan nasabah sebagai mitra usaha sektor riil hal ini juga didukung dengan implementasi pada PT. Bank Muamalat Indonesia Cabang Pekanbaru sesuai dengan visi dan misi yang telah ditetapkan.

Variabel keenam adalah fisik dianggap dapat mempengaruhi Tabungan Shar-e karena dengan adanya bukti fisik nasabah dapat dengan mudah mengenali poduk-produk PT. bank Muamalat Indonesia cabang pekanabaru.bukt fisik disini dapat berupa kebijakan- kebijakan yang telah dikeluarkan oleh manajemen PT. Bank Muamalat Indonesia cabang Pekanbaru.

Variable ketujuh adalah proses dianggap dapat mempengaruhi Tabungan Shar-e karena proses dari tabungan Shar-e sangat mudah, baik itu dari segi prosedur, jadwal pekerjaan, mekanisme, aktivitas, dan hal-hal rutin.

\section{SIMPULAN}

a. PT. Bank Muamalat Indonesia Cabang Pekanbaru adalah salah satu Perbankan Syariah di Pekanbaru yang memasarkan produk dan jasa, oleh karena itu perusahaan harus bisa meningkatkan jumlah nasabah setiap tahunnya untuk mengalokasikan dana pada PT. Bank Muamalat Indonesia Cabang Pekanbaru.

b. Dari penjelasan pada pembahasan uji analisis data dengan regresi linear berganda, koefisien determinasi $\left(\mathrm{R}^{2}\right) / \mathrm{R}$ square, uji $\mathrm{F}$, dan uji $\mathrm{T}$, menjelaskan bahwa variabel bebas produk/produck (X1), harga/price (X2), promosi/promotion (X3), distribusi/distribution orang/people (X5), fisik/physic (X6), proses/proses (X7) mempunyai pengaruh yang sangat signifikan terhadap variabel terikat yaitu Tabungan Shar-e (Y) pada PT. Bank Muamalat Indonesia Cabang Pekanbaru.

c. Dari hasil penelitian diketahui bahwa variabel bebas (produk/produck, harga/price, promsi/promotion, distribusi/place, orang/people, fisik/physical, proses/proses) bersama-sama mempengaruhi Tabungan Shar-e pada PT. Bank Muamalat Indonesia Cabang Pekanbaru. Hal ini dibuktikan dari hasil analisis dengan program komputer SPSS 12 terhadap variabel bebas diatas, yang ditunjukkan oleh uji F dengan nilai Sig. 0,013 < taraf Sig. 0,05 artinya semua variabel mempunyai pengaruh yang signifikan terhadap perilaku konsumen. 
d. Berdasarkan hasil perhitungan diketahui bahwa nilai Koefisien Determinasi $\left(R^{2}\right)$ sebesar 0,751 atau sebesar 75,10\%, hal ini menunjukkan bahwa ketujuh variabel bebas (produk/ produck, harga/price, promsi/promotion, distribusi/place, orang/people, fisik/physical, proses/proses) secara bersama-sama mampu menjelaskan terhadap variabel terikatnya sebesar $75,10 \%$ sedangkan sisanya $24,9 \%$ lagi (100 $75,1)$ dapat diterangkan oleh variabel lain yang tidak diteliti pada penelitian ini.

\section{DAFTAR RUJUKAN}

Alma, Buchari. (2000). Manajemen Pemasaran dan Pemasaran Jasa. Erlangga, Jakarta.

Alma, Buchari dan Huryati Ratih. (2008). Manajemen Coperate dan Strategi Pemasaran Jasa Pendidikan. Alfabeta, Bandung.

Angipora, Marius, P. (2002). Dasar-dasar Pemasaran. PT.Raja Grafindo Persada, Jakarta.

Antonio, Safi'I Muhammad. (2001). Bank Syariah dari Tiori Keperaktek. Gema Insani, Jakarta.

Ascarya. (2007). Akad dan Produk Bank Syariah. PT. Raja Grafindo Persada, Jakarta.

Assauri, Sofjan. (2004). Manajemen Pemasaran, Dasar, Konsep Dan Strategi. PT. Raja Grafindo Persada, Jakarta.

Basu Swasta, DH dan Iriawan. (2002). Manajemen Pemasaran Modren. Liberti, Yogyakarta.

David W. Cravens. (2002). Pemasaran Strategis. Bina Rupa Aksara, Jakarta Barat.

Ghozali, Imam. (2005). Analisis Multivariate Dengan Program SPSS. Badan
Penerbit Universitas Diponegoro, Semarang.

Hamzah, Z., Arif, M., \& Nisa, C. (2019). Analisis Komparasi Strategi Pemasaran Dalam Transaksi Jual Beli Online Dan Offline Pada Hijab (STUDI Kasus: Mahasiswa Universitas Islam Riau). Syarikat: Jurnal Rumpun Ekonomi Syariah, 2(1), 16-26.

Kartajaya, Hermawan dan Sula Syakir Muhammad. (2006). Syariah Markeing, PT. Media Pustaka, Bandung.

Kasmir. (2005). Pemasaran Bank. Kencana, Jakarta.

Keegon, Warren J. (2003). Manajemen Pemasaran Global. Jilid 2, PT. Indeks. Jakarta.

Kotler, Philip. (2004). Dasar-Dasar Pemasaran, Edisi Kesembilan. PT. Indeks, Jakarta.

Lamb, Hair, Mc Daniel. (2001). Pemasaran. Thomson Learning, Jakarta.

Lupiyoadi. (2001). Marketing Plus 2000 Siasat Memenangkan Persaingan Global. Gramedia, Jakarta.

Lupiyoadi dan Hamdani. (2006). Manajemen Pemasaran Jasa. Salemba Empat, Jakarta.

Maksum, Habibi. (2002). Ekonomi. Yudistira, Jakarta.

McDaniel, Carl. (2001). Riset Pemasaran Kontemporer. Grand Wijaya Center, Jakarta.

M. Taufiq, Amir. (2005). Dinamika pemasaran. PT. Raja Grafindo Persada, Jakarta.

Philip Kotler dan Amstrong. (2003). Prinsip Pemasaran. Erlangga, Jakarta.

Philip Kotler dan Susanto. (2001). Manajemen Pemasaran di Indonesia. Selemba Empat, Jakarta. (2002). Edisi

Millenium. Prehallindo, Jakarta. 
Saladin, Djamil. (2003). Manajemen

Pemasaran. Erlangga, Jakarta

Sula, syakir Muhammad. (2004). Asuansi

Syariah. Gema Insani, Jakarta.

Sumarni, Murti. (2002). Manajemen

Pemasaran Bank. Liberty,

Jogyakarta. 